JRKA Volume 3 Isue 1, Februari 2017: 41 - 52

\title{
ANALISIS KINERJA SAHAM SYARIAH SEKTOR PERTANIAN DENGAN MENGGUNAKAN METODE SHARPE, TREYNOR, DAN JENSEN
}

\author{
Juwenah \\ Unswagati Cirebon \\ juwenah.juwenah@yahoo.co.id \\ Firman Hidayat \\ Unswagati Cirebon \\ man_crb14@yahoo.co.id
}

\begin{abstract}
This research is aimed to detect Performance of Sharia Stock Agricultur Sector in Indonesia, especially kind of Stock of within research period 2012-2016. The performance measuring method that is used is Sharpe, Treynor, and Jensen Method. The Data which is used in this research is secondary data by using sample interpretation technique, use purposive sampling. Analysis Technique which is used in this research is decriptive with quantitative approach.

The performance of Sharia Stock's by using Sharpen's Method, its founded four Sharia Stock which have Under Performance, those are: PT. Astra Agro Lestari Tbk (AALI), PT Gozco Plantations Tbk (GZCO), PT Sampoerna Agro Tbk (SGRO), dan PT Salim Ivomas Pratama Tbk (SIMP), and also there are five Sharia Stock which have out perform, those are: PT BISI International Tbk (BISI), PT Bumi Teknokultura Unggul Tbk (BTEK), PT Dharma Samudera Fishing Industries Tbk (DSFI), PT Inti Agri Resources Tbk (IIKP), dan PT PP London Sumatra Indonesia Tbk (LSIP).

The Performance of Sharia Stock's by using Treynor Method, there are five Sharia Stock which have under perform, those are PT. Astra Agro Lestari Tbk (AALI), PT Gozco Plantations Tbk (GZCO), PT PP London Sumatra Indonesia Tbk (LSIP), PT Sampoerna Agro Tbk (SGRO), dan PT Salim Ivomas Pratama Tbk (SIMP), and also there are four Sharia Stock which have out perform, Those are PT BISI International Tbk (BISI), PT Bumi Teknokultura Unggul Tbk (BTEK), PT Dharma Samudera Fishing Industries Tbk (DSFI), dan PT Inti Agri Resources Tbk (IIKP).

For Sharia Stock's performance by using Jensen Method cant be achieved the decision whether sharia stock has out perform or under perform.

Key word: Performance, Sharia Stock, Sharpe, Treynor, Jensen

\section{PENDAHULUAN}

Perkembangan pasar modal syariah di Indonesia selama dua dekade ini telah mengalami kemajuan, yaitu dimulai sejak pertama kali diluncurkannya reksa dana

syariah pada tahun 1997. Sosialisasi dan edukasi tentang pasar modal syariah juga semakin banyak dilakukan, baik melalui pendidikan formal ataupun sosialisasi dengan menggunkan media informasi dan media lainnya. Disamping itu, pasar
\end{abstract}


modal syariah semakin berkembang dengan ditandai banyaknya produk syariah, diterbitkannya regulasi terkait pasar modal syariah, dan semakin bertambahnya masyarakat yang mengenal dan peduli terhadap pasar modal syariah.

Produk-produk syariah yang tersedia hingga akhir tahun 2014 terdiri dari efek syariah berupa saham syariah, sukuk, reksadana syariah, dan exchange traded funds (ETF) syariah, serta layanan syariah berupa online trading syariah. Dilihat dari kerangka hukum, indonesia telah memiliki regulasi pasar modal syariah yang didasarkan pada fatwa yang diterbitkan oleh Dewan Syariah Nasional-Majelis Ulama Indonesia (DSN-MUI).

Perkembangan pasar modal syariah yang telah dicapai merupakan hasil kerja keras regulator dan seluruh stake holders dalam mengimplementasikan strategi pengembangan pasar modal syariah. Perkembangan pasar modal tersebut patut diapresiasi. Akan tetapi, mengingat bahwa market share produk syariah di pasar modal yang masih relatif kecil, maka diperlukan strategi pengembangan yang terencana untuk mewujudkan pasar modal syariah yang memberikan kontribusi signifikan bagi perekonomian nasional, berkeadilan, dan melindungi kepentingan masyarakat. Hal-hal yang memerlukan pengembangan lebih lanjut adalah aspek regulasi, produk, sumber daya manusia, tekhnologi informasi, serta promosi dan edukasi mengenai pasar modal syariah juga perlu mendapatkan perhatian yang lebih besar.

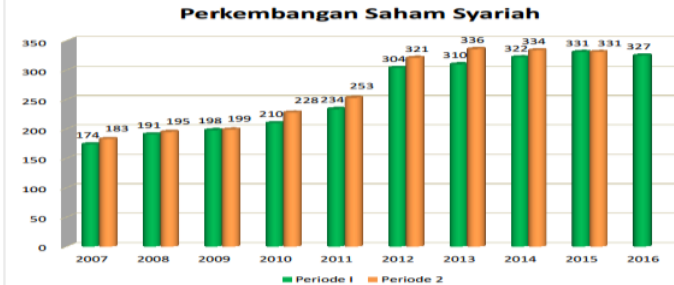

Sumber: otoritas jasa keuangan

Gambar 1.1

Perkembangan Saham Syariah

Berdasarkan gambar diatas, terlihat bahwa perkembangan saham syariah setiap tahun mengalami kenaikan. Pergerakan saham syariah dari tahun 2007 sampai tahun 2016 naik, meskipun pada tahun 2016 mengalami penurunan dari 331 menjadi 327, tetapi penurunan tersebut tidak terlalu signifikan.

Saham syariah di Indonesia sebagian besar merupakan saham yang diterbitkan oleh emiten yang bukan merupakan entitas syariah. Saham syariah tersebut merupakan saham yang memenuhi kriteria saham syariah yang ditetapkan oleh Otoritas Jasa Keuangan yang dimuat dalam Daftar Efek Syariah (DES). Memilih portofolio, selain mempertimbangkan aspek kesyariahan, investor syariah memiliki preferensi terhadap saham syariah, apabila kinerja saham lebih baik dibandingkan saham non syariah. Oleh karena itu, perlu adanya kajian atau penelitian untuk mengetahui sejauh mana kinerja saham syariah dibandingkan dengan saham non syariah. Kajian tersebut dimaksudkan untuk membuktikan ketahanan kinerja saham syariah ketika terjadi krisis keuangan. Mengingat bahwa salah satu kriteria saham syariah adalah rasio utang berbasis bunga dibandingkan total aset tidak lebih dari 45\%, maka saham syariah diharapkan mempunyai ketahanan yang 
lebih dalam kondisi krisis keuangan. (OJK)

Berdasarkan hal yang sudah dipaparkan, peneliti tertarik untuk menganalisis kinerja Saham Saham Syariah khususnya sektor pertanian periode 2012-2016. Hal ini penting dilakukan untuk membantu para investor dan calon investor dalam memilih Saham Syariah yang paling baik sesuai dengan rangkingnya selama periode tersebut dan menganalisis saham syariah mana saja yang outperform atau underperform setiap tahunhya.

Penelitian ini menggunakan metode Sharpe, Treynor dan Jensen sebagai metode menganalisis kinerja saham melalui tingkat keuntungan dan risiko dari sebuah Saham Syariah. Ketiga metode tersebut mempunyai karakteristik yang berbeda-beda, sehingga para investor dapat menilai kinerja Saham Syariah dari berbagai sudut pandang. Metode Sharpe menggunakan risiko individu (standar deviasi) sebagai dasar pengujiannya.

\section{TINJAUAN PUSTAKA}

\section{A. Saham Syariah}

Berdasarkan Fatwa Dewan Syariah Nasional No. 59 tahun 2007 tentang obligasi syariah mudhorobah konversi, saham syariah adalah sertifikat yang menunjukkan bukti kepemilikan suatu porsi dalam perusahaan yang diterbitkan oleh emiten yang kegiatan usaha maupun cara pengelolaannya tidak bertentangan dengan prinsip syariah.

\section{B. Kriteria Pemilihan Saham Syariah \\ Kriteria pemilihan saham syariah didasarkan kepada Peraturan Bapepam- LK (sekarang menjadi OJK) No.II.K.1}

tentang Kriteria dan Penerbitan Daftar Efek syariah, Pasal 1.b.7 dan Peraturan Otoritas Jasa Keuangan No.15/POJK.04/2015 Tentang Penerapan Prinsip Syariah Di Pasar Modal disebutkan bahwa Efek berupa saham, termasuk HMETD syariah dan Waran syariah, yang diterbitkan oleh Emiten atau Perusahaan Publik yang tidak menyatakan bahwa kegiatan usaha serta cara pengelolaan usahanya dilakukan berdasarkan prinsip syariah, sepanjang Emiten atau Perusahaan Publik tersebut:

1. Tidak melakukan kegiatan usaha sebagaimana dimaksud dalam angka 1 huruf $b$ Peraturan Nomor IX.A.13, yaitu:

Kegiatan usaha yang bertentangan dengan prinsip-prinsip syariah antara lain:

a. Perjudian dan permainan yang tergolong judi;

b. Perdagangan yang dilarang menurut syariah, antara lain :

1) perdagangan yang tidak disertai dengan penyerahan barang/jasa; dan

2) perdagangan dengan penawaran/permintaan palsu;

c. Jasa keuangan ribawi, antara lain:

1) bank berbasis bunga; dan

2) perusahaan pembiayaan berbasis bunga;

d. Jual beli risiko yang mengandung unsur ketidakpastian (gharar) dan/atau judi (maisir), antara lain asuransi konvensional;

e. Memproduksi, mendistribusikan, memperdagangkan dan/atau menyediakan antara lain:

1) barang atau jasa haram zatnya (haram li-dzatihi);

2) barang atau jasa haram bukan karena zatnya (haram li- 
ghairihi) yang ditetapkan oleh DSN-MUI; dan/atau

f. melakukan transaksi yang tidak sesuai dengan prinsip syariah di pasar modal

2. Memenuhi rasio-rasio keuangan sebagai berikut:

a. Total utang yang berbasis bunga dibandingkan dengan total assets tidak lebih dari $45 \%$ (empat puluh lima per seratus);

b. Total pendapatan bunga dan pendapatan tidak halal lainnya dibandingkan dengan total pendapatan usaha (revenue) dan pendapatan lain-lain tidak lebih dari $10 \%$ (sepuluh per seratus)

\section{Kinerja}

Untuk mengetahui apakah sasaran investor masih tercapai, maka kinerja portofolio perlu dihitung dan diukur setiap saat dan dibandingkan dengan benchmark sasaran investor. Pengukuran kinerja portofolio tidak cukup hanya return nya saja, tetapi harus mempertimbangkan risiko juga, karena adanya tukaran (trade-off).

Pengukuran kinerja portofolio merupakan perkembangan konsep portofolio yang terjadi pada akhir tahun 1960-an yang dipelopori oleh William F. Sharpe, Trenor, dan Jensen. Konsep tersebut berdasarkan teori capital market dan dikenal dengan istilah composite (risk-adjusted) measure of portofolio performance karena mengkombinasikan antara return dan risk dalam suatu perhitungan. (Jogiyanto, 2014).

Analisis kinerja saham menggunakan metode Jensen, Sharpe, dan Treynor perlu dilakukan kajian, karena dalam pengelolaan portofolio baik manajer investasi maupun investor individu akan melakukan beberapa tahapan. Metode tersebut dapat digunakan dengan melihat kondisi pasar yang sedang berlangsung. Metode Jensen menekankan pada Alpha, Sharpe menekankan pada risiko total (deviasi standar), dan Treynor menekankan pada fluktuasi pasar yang sangat berperan dalam mempengaruhi return (beta). (Teurah, 2013).

\section{METODE PENELITIAN}

\section{A. Jenis Penelitian}

Penelitian ini merupakan penelitian kuantitatif. Sugiyono (2014) mendefinisikan penelitian kuantitatif adalah metode penelitain yang berlandaskan pada filsafat positivisme, digunakan untuk meneliti pada populasi atau sampel tertentu, pengumpulan data menggunakan instrumen penelitian, analisis data bersifat kuantitatif/statistik, dengan tujuan untuk menguji hipotesis yang telah ditetapkan.

Menurut Moleong (2013) berdasarkan tujuan nya penelitian kuantitatif bertujuan menjelaskan, meramalkan, dan/atau mengontrol fenomena melalui pengumpulan data berfokus dari data numerik.

\section{B. Variabel Penelitian}

Variabel-variabel yang digunakan dalam penelitian ini Return Saham syariah, Return IHSG (benchmark), Standar Deviasi Return Saham, Risk free, Beta portofolio, alpha, Metode Sharpe, Metode Treynor, dan Metode Jensen.

\section{Definisi Operasional}

Variabel-variabel operasional penelitian yang sudah ditetapkan memiliki definisi sebagai berikut:

1. Return

Return saham syariah dalam periode tertentu yang menunjukkan suatu ukuran kinerja yang telah dicapai perusahaan yang diperhitungkan dari data closing harga saham. Return Saham dapat dihitung dengan rumus: 


$$
R p, t=\frac{H \arg \operatorname{SSaham}_{t}-H \arg \operatorname{aSaham}_{t-1}}{H \arg \operatorname{aSaham}_{t-1}}
$$

Keterangan: $R p_{\mathrm{t}} \quad=$ Return Saham pada waktu $\mathrm{t}$

\section{Return IHSG (Benchmark)}

Suatu ukuran kemampuan kinerja pasar sebagai pembanding dalam menunjukkan suatu kinerja yang telah dicapai dalam periode tertentu yang perhitungannya diperoleh dari nilai IHSG. Return pada IHSG dapat dihitung dengan rumus:

$$
R_{m, t}=\frac{I H S G_{t}-I H S G_{t-1}}{I H S G_{t-1}}
$$

Keterangan:

$\mathrm{IHSG}_{\mathrm{t}}=$ Indeks Harga Saham pada waktu t

$\mathrm{IHSG}_{\mathrm{t}-1}=$ Indeks Harga Saham pada waktu t-1

\section{Standar Deviasi Return Saham}

Standar deviasi menggambarkan penyimpangan yang terjadi dari rata-rata return yang dihasilkan pada saham dan pasar pada sub periode tertentu. Standar deviasi return saham dapat diketahui dengan rumus:

$$
\sigma=\sqrt{\sigma^{2}}=\sqrt{\frac{\sum_{i=1}^{n}\left(r_{i}-\bar{r}_{i}\right)^{2}}{(n-1)}}
$$

Keterangan:

$\mathrm{r}_{\mathrm{i}} \quad$ : tingkat keuntungan saham $\mathrm{i}$

$\bar{r}_{i}$ : tingkat keuntungan rata-rata saham

n : jumlah sampel

\section{Risk Free}

Merupakan investasi dengan bebas risiko yang diasumsikan dengan tingkat rata-rata suku bunga Sertifikat Bank Indonesia (SBI) pada periode tertentu. Risk Free dapat dihitung dengan rumus:

$$
R_{f}=\frac{\sum S B I}{\sum \text { Periode }}
$$

Keterangan: ${ }^{R_{f}}$ : Risk Free

\section{Metode Sharpe}

Merupakan metode yang digunakan untuk mengukur kinerja saham yang didasarkan pada seberapa besar penambahan hasil investasi yang diperoleh untuk setiap unit risiko yang diambil. Mengukur kinerja metode sharpe dapat dihitung dengan rumus:

$$
\mathrm{R} / \mathrm{V}_{\mathrm{s}}=\frac{\overline{\boldsymbol{R}}_{p}-\overline{\boldsymbol{R}}_{f}}{\text { op }}
$$

Keterangan:

$\bar{R}_{p} \quad=$ Rata-rata return portofolio saham

$\bar{R}_{f} \quad=$ Rata-rata Risk free pada aset lain

$\sigma p=$ Standar Deviasi return portofolio saham

6. Metode Treynor

Pengukuran kinerja saham metode Treynor dan metode Sharpe menggunakan Risk Premium, tetapi metode Treynor menggunakan beta $(\beta)$ yang merupakan risiko fluktuasi realtif terhadap risiko pasar. Metode Treynor dapat dihitung dengan rumus:

$$
E R B=\frac{\bar{R}_{i}-\bar{R}_{f}}{\beta_{i}}
$$


Keterangan: $\overline{\mathrm{R}} \mathrm{i}=$ Rata-rata return saham $\mathrm{i}$ $\mathrm{R}_{\mathrm{f}}=$ Risk free pada aset lain $\beta_{\mathrm{i}}=$ beta saham $\mathrm{i}$

\section{Metode Jensen}

Model pengukuran Jensen's Alpha adalah model pengukuran yang menggunakan nilai intersep (intercept) untuk menentukan kinerja suatu portofolio. Semakin tinggi intersep yang dihasilkan, maka semakin tinggi imbal hasil (return) portofolionya. Model pengukuran Jensen's Alpha didasarkan pada konsep garis pasar sekuritas (security market line) yaitu garis yang menghubungkan portofolio pasar dengan kesempatan investasi yang bebas risiko. Rumus untuk menghitung Indeks Jensen adalah sebagai berikut:

$$
\mathrm{Rpt}-\mathrm{Rf}=\alpha+\beta(\mathrm{Rmt}-\mathrm{Rf})+\sum \mathrm{pt}
$$

Keterangan:

$\mathrm{Rpt}=$ Return for the scheme

$\alpha=\bar{R}_{p}-\mathrm{E} \bar{R}_{\mathrm{j}}$ (Rata-rata return portofolio saham - Expected Return)

$\mathrm{Rf}=$ Risk free return

$\mathrm{Rmt}=$ Return on the market portofolio

$\sum \mathrm{pt}=$ Random error term

\section{Populasi dan sampel}

Berdasarkan Keputusan Dewan Komisioner Otoritas Jasa Keuangan No.22 Tahun 2016 tentang Daftar Efek Syariah, terdapat 321 emiten saham syariah yang terdaftar di Bursa Efek Indonesia. 311 emiten Saham syariah yang sudah listing, dan 10 emiten saham syariah yang tidak listing. Penelitian ini mengambil sampel sektor pertanian yang terdiri dari 11 Perusahaan. Penelitian ini hanya mengambil 9 perusahaan karena PT. Sawit Sumbermas Sarata Tbk dan PT. Austindo Nusantara Jaya Tbk baru launching pertengahan tahun 2013, sedangkan periode penelitian ini dari tahun 2012 sampai tahun 2016. Metode pengambilan sampel menggunakan pendekatan purposive sampling.

Tabel 3.1

Daftar Saham Syariah Sektor Pertanian Periode Tahun 2012-2016

\begin{tabular}{|c|c|l|}
\hline No. & $\begin{array}{c}\text { Kode } \\
\text { Saham }\end{array}$ & \multicolumn{1}{c|}{ Nama Penerbit Efek } \\
\hline \hline 1. & AALI & PT Astra Agro Lestari Tbk. \\
\hline 2. & ANJT & PT Austindo Nusantara Jaya Tbk. \\
\hline 3. & BISI & PT BISI International Tbk. \\
\hline 4. & BTEK & PT Bumi Teknokultura Unggul Tbk. \\
\hline 5. & DSFI & PT Dharma Samudera Fishing Industries Tbk. \\
\hline 6. & GZCO & PT Gozco Plantations Tbk. \\
\hline 7. & IIKP & PT Inti Agri Resources Tbk. \\
\hline 8. & LSIP & PT PP London Sumatra Indonesia Tbk. \\
\hline 9. & SGRO & PT Sampoerna Agro Tbk. \\
\hline 10. & SIMP & PT Salim Ivomas Pratama Tbk. \\
\hline 11. & SSMS & PT Sawit Sumbermas Sarana Tbk. \\
\hline
\end{tabular}

Sumber: Otoritas Jasa Keuangan

\section{E. Teknik Analisis Data}

Penelitian ini menggunakan analisa kuantitatif dari data yang tersedia, penilaian kinerja saham syariah menggunakan Metode Sharpe, Metode Treynor dan Metode Jensen. Metode analisis kinerja Saham Syariah digunakan melalui beberapa tahap, yaitu:

1. Analisis Penilaian Kinerja Saham Syariah Metode Sharpe

2. Analisis Penilaian Kinerja Saham Syariah metode Treynor

3. Analisis Penilaian Kinerja Saham Syariah Metode Jensen 
HASIL DAN PEMBAHASAN

A. Analisis Return Saham Syariah dengan Kinerja Pasar

Return dari masing-masing saham syariah dihitung berdasarkan harga sahamnya. Berikut contoh perhitungan return saham PT BISI International Tbk (BISI) pada tanggal 1 Februari 2012:

PT BISI International Tbk (BISI)

$$
910
$$

Berdasarkan

perhitungan diperoleh return sebesar 0,01099, kemudian dijumlahkan selama 1 tahun diperoleh jumlah return sebesar -0,00474. Sedangkan rata-rata return tahunan selama 2012 sebesar -0,00043.

Perhitungan return saham syariah dan IHSG lainnya pada tahun 2012 sampai tahun 2016 dihitung menggunakan cara yang sama, untuk lebih lengkapnya terdapat pada Tabel 4.1.

Tabel 4.1

Rata-Rata Return Saham Syariah Periode Tahun 2012-2016 tahun $2012=\underline{920-910}=0,01099$

Keterangan:

$\mathrm{r}_{\mathrm{i}} \quad$ :tingkat keuntungan saham $\mathrm{i}$

$\bar{r}_{i}$ : tingkat keuntungan rata-rata

saham

n : jumlah sampel

Hasil perhitungannya dapat dilihat pada

Tabel 4.2.

Tabel 4.2

Standar Deviasi Saham Syariah

\begin{tabular}{|l|l|c|r|r|r|c|}
\hline \multirow{2}{*}{ No } & Saham & \multicolumn{5}{|c|}{ Standar Deviasi Saham Syariah } \\
\cline { 3 - 7 } & Syariah & $\mathbf{2 0 1 2}$ & $\mathbf{2 0 1 3}$ & $\mathbf{2 0 1 4}$ & $\mathbf{2 0 1 5}$ & $\mathbf{2 0 1 6}$ \\
\hline 1 & AALI & 0.081641 & 0.126693 & 0.092841 & 0.117558 & 0.113727 \\
\hline 2 & BISI & 0.173577 & 0.080844 & 0.170955 & 0.160349 & 0.088975 \\
\hline 3 & BTEK & 0.140336 & 0.24491 & 0.096123 & 0.110484 & 0.187396 \\
\hline 4 & DSFI & 0.084086 & 0.05165 & 0.354632 & 0.335426 & 0.215249 \\
\hline 5 & GZCO & 0.153631 & 0.048994 & 0.111551 & 0.161575 & 0.108371 \\
\hline 6 & IIKP & 0.061253 & 0.162646 & 0.160832 & 0.62628 & 0.062372 \\
\hline 7 & LSIP & 0.126914 & 0.2085 & 0.107382 & 0.159599 & 0.121455 \\
\hline 8 & SGRO & 0.104926 & 0.073388 & 0.084185 & 0.135804 & 0.034297 \\
\hline 9 & SIMP & 0.097215 & 0.113932 & 0.081717 & 0.07357 & 0.102991 \\
\hline & IHSG & 166.139 & 317.4164 & 246.4153 & 439.9813 & 280.6774 \\
\hline
\end{tabular}

Tabel 4.3

SBI, SD, IHSG dan Return Bulanan IHSG

\begin{tabular}{|c|c|c|c|c|c|}
\hline Keterangan & 2012 & 2013 & 2014 & 2015 & 2016 \\
\hline SBI & 0.003683 & 0.004807 & 0.005838 & 0.00563 & 0.005373 \\
\hline ataI-Rat: & \multicolumn{3}{|c|}{ 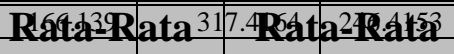 } & 439.9813 & 280.6774 \\
\hline 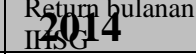 & 0.012891 & & 01.697055 & -0.01117 & 0.013679 \\
\hline
\end{tabular}

\begin{tabular}{rl|r|r|}
\hline 1 & AALI & -0.00383 & 0.03017171 \\
\hline 2 & BISI & -0.00043 & -0.026143666 \\
\hline 3 & BTEK & -0.01928 & 0.060892526 \\
\hline 4 & DSFI & 0.011917 & -0.004996086 \\
\hline 5 & GZCO & -0.02034 & -0.047028349 \\
\hline 6 & IIKP & 0.032656 & 0.049178662 \\
\hline 7 & LSIP & 0.000751 & 0.007521714 \\
\hline 8 & SGRO & -0.0174 & -0.014345443 \\
\hline 9 & SIMP & -0.00407 & -0.024491521 \\
\hline \multicolumn{5}{|c|}{ IHSG } & 0.010832 & 0.000303513 \\
\hline
\end{tabular}

Standar Deviasi dari masing-masing saham syariah dan IHSG dapat dihitung dengan rumus berikut:

$$
\sigma=\sqrt{\sigma^{2}}=\sqrt{\frac{\sum_{i=1}^{n}\left(r_{i}-\overline{r_{i}}\right)^{2}}{(n-1)}}
$$


Tabel 4.4 menunjukkan bahwa dengan menggunakan metode Sharpe selama tahun 2012 kinerja saham syariah menghasilkan kinerja yang negatif, kecuali PT Dharma Samudera Fishing Industries Tbk (DSFI) dan PT Inti Agri Resources Tbk (IIKP) . Pada tahun 2013 terdapat empat kinerja saham syariah yang positif yaitu: AALI, BTEK, IIKP, dan LSIP, sedangkan yang lima saham syariah lainnya memiliki kinerja negatif. Pada tahun 2014 terdapat lima kinerja saham yang positif, yaitu: BISI, DSFI, GZCO, IIKP, dan SGRO, sedangkan empat saham lainnya memiliki kinerja negatif. Pada tahun 2015 terdapat tiga kinerja saham yang positif, yaitu: BISI, BTEK, dan IIKP, sedangkan enam saham lainnya memiliki kinerja negatif. Pada tahun 2016 terdapat enam kinerja saham yang positif, yaitu: AALI, BISI, DSFI, LSIP, SGRO, dan SIMP, sedangkan tiga saham lainnya memiliki kinerja negatif.

Saham syariah dengan hasil kinerja positif menunjukkan bahwa return yang dihasilkan melebihi return investasi bebas risiko. Semakin besar hasil yang diperoleh maka semakin baik pula kinerja suatu saham syariah karena memberikan return yang tinggi atas risiko individual yang ditanggungnya.

Nilai beta sangat berpengaruh dalam menghitung kinerja saham dengan menggunakan metode Treynor. Nilai beta dapat dihitung dengan rumus:

$$
\beta=\frac{S D_{-} \text {reksadana }}{S D_{-} I H S G}
$$

Nilai beta saham syariah pada periode tahun 2012-2016 dapat dilihat pada perhitungan tabel 4.5 .

Tabel 4.5

Hasil Perhitungan Nilai Beta

\begin{tabular}{|c|c|c|c|c|c|c|}
\hline \multirow{2}{*}{ No } & \multirow{2}{*}{$\begin{array}{c}\text { Saham } \\
\text { Syariah }\end{array}$} & \multicolumn{5}{|c|}{ Nilai Beta } \\
\hline & & 2012 & 2013 & 2014 & 2015 & 2016 \\
\hline 1 & AALI & 0.000491 & 0.000399 & 0.000377 & 0.000267 & 0.000405 \\
\hline 2 & BISI & 0.001045 & 0.000255 & 0.000694 & 0.000364 & 0.000317 \\
\hline 3 & BTEK & 0.000845 & 0.000772 & 0.00039 & 0.000251 & 0.000668 \\
\hline 4 & DSFI & 0.000506 & 0.000163 & 0.001439 & 0.000762 & 0.000767 \\
\hline 5 & GZCO & 0.000925 & 0.000154 & 0.000453 & 0.000367 & 0.000386 \\
\hline 6 & IIKP & 0.000369 & 0.000512 & 0.000653 & 0.001423 & 0.000222 \\
\hline 7 & LSIP & 0.000764 & 0.000657 & 0.000436 & 0.000363 & 0.000433 \\
\hline 8 & SGRO & 0.000632 & 0.000231 & 0.000342 & 0.000309 & 0.000122 \\
\hline 9 & SIMP & 0.000585 & 0.000359 & 0.000332 & 0.000167 & 0.000367 \\
\hline \multicolumn{2}{|r|}{ IHSG } & 1 & 1 & 1 & 1 & 1 \\
\hline
\end{tabular}

Tabel 4.6

Hasil Perhitungan Metode Treynor

\begin{tabular}{|c|c|c|c|c|c|c|}
\hline \multirow{2}{*}{ No } & \multirow{2}{*}{$\begin{array}{l}\text { Saham } \\
\text { Syariah }\end{array}$} & \multicolumn{5}{|c|}{ Metode Treynor } \\
\hline & & 2012 & 2013 & 2014 & 2015 & 2016 \\
\hline 1 & AALI & -15.2842 & 63.54932 & -12.8389 & -127.965 & 22.78025 \\
\hline 2 & BISI & -3.93713 & -121.52 & 49.32062 & 142.2833 & 84.92415 \\
\hline 3 & BTEK & -27.1893 & 72.68994 & -44.6369 & 117.2779 & -32.3932 \\
\hline 4 & DSFI & 16.26886 & -60.2442 & 105.0695 & -24.7854 & 60.65547 \\
\hline 5 & GZCO & -25.9801 & -335.821 & 36.05618 & -63.4532 & -50.1442 \\
\hline 6 & IIKP & 78.58488 & 86.59503 & 63.01275 & 93.35011 & -156.255 \\
\hline 7 & LSIP & -3.83768 & 4.133066 & -5.83149 & -64.7489 & 56.08863 \\
\hline 8 & SGRO & -33.389 & -82.8372 & 4.124706 & -47.4777 & 40.19416 \\
\hline 9 & SIMP & -13.2506 & -81.6254 & -33.8485 & -381.746 & 88.82128 \\
\hline & IHSG & 0.007149 & -0.0045 & 0.011217 & $\begin{array}{l}-0.0168 \\
\end{array}$ & 0.008306 \\
\hline
\end{tabular}

Tabel 4.6 menunjukkan bahwa dengan menggunakan metode Treynor, selama tahun 2012 kinerja saham syariah mengalami kinerja yang negatif, kecuali saham syariah PT Dharma Samudera Fishing Industries Tbk (DSFI) dan PT Inti Agri Resources Tbk (IIKP). Pada tahun 2013 terdapat empat kinerja saham syariah yang positif yaitu: AALI, BTEK, IIKP, dan LSIP, sedangkan yang lima saham syariah lainnya memiliki kinerja negatif. Pada tahun 2014 terdapat lima kinerja saham yang positif, yaitu: BISI, DSFI, GZCO, IIKP, dan SGRO, sedangkan empat saham lainnya memiliki kinerja negatif. Pada tahun 2015 terdapat tiga kinerja saham yang positif, yaitu: BISI, BTEK, dan IIKP, sedangkan enam saham lainnya memiliki kinerja negatif. Pada tahun 2016 terdapat enam kinerja saham yang positif, yaitu: AALI, BISI, DSFI, LSIP, SGRO, dan SIMP, 
sedangkan tiga saham lainnya memiliki kinerja negatif.

Tabel 4.7

Hasil Perhitungan Metode Jensen

\begin{tabular}{|c|c|c|c|c|c|c|}
\hline \multirow{2}{*}{ No } & \multirow{2}{*}{$\begin{array}{l}\text { Saham } \\
\text { syariah }\end{array}$} & \multicolumn{5}{|c|}{ Metode Jensen } \\
\hline & & 2012 & 2013 & 2014 & 2015 & 2016 \\
\hline 1 & AALI & -0.00751 & 0.025367 & -0.00484 & -0.03419 & 0.009227 \\
\hline 2 & BISI & -0.00412 & -0.03095 & 0.034209 & 0.05186 & 0.026918 \\
\hline 3 & BTEK & -0.02297 & 0.056089 & -0.01742 & 0.029454 & -0.02163 \\
\hline 4 & DSFI & 0.00823 & -0.0098 & 0.151196 & -0.01888 & 0.04651 \\
\hline 5 & GZCO & -0.02403 & -0.05183 & 0.016317 & -0.0233 & -0.01936 \\
\hline 6 & IIKP & 0.028971 & 0.044374 & 0.04112 & 0.132901 & -0.03472 \\
\hline 7 & LSIP & -0.00294 & 0.002718 & -0.00255 & -0.02348 & 0.024267 \\
\hline 8 & SGRO & -0.02109 & $\begin{array}{l}-0.01915 \\
\end{array}$ & 0.001405 & -0.01465 & 0.00491 \\
\hline 9 & SIMP & -0.00776 & -0.0293 & -0.01123 & -0.06383 & 0.032589 \\
\hline & HSG & 0 & 0 & 0 & 0 & 0 \\
\hline
\end{tabular}

Tabel 4.7 menunjukkan bahwa dengan menggunakan metode Jensen, selama tahun 2012 kinerja saham syariah mengalami kinerja yang negatif, kecuali saham syariah PT Dharma Samudera Fishing Industries Tbk (DSFI) dan PT Inti Agri Resources Tbk (IIKP). Pada tahun 2013 terdapat empat kinerja saham syariah yang positif yaitu: AALI, BTEK, IIKP, dan LSIP, sedangkan yang lima saham syariah lainnya memiliki kinerja negatif. Pada tahun 2014 terdapat lima kinerja saham yang positif, yaitu: BISI, DSFI, GZCO, IIKP, dan SGRO, sedangkan empat saham lainnya memiliki kinerja negatif. Pada tahun 2015 terdapat tiga kinerja saham yang positif, yaitu: BISI, BTEK, dan IIKP, sedangkan enam saham lainnya memiliki kinerja negatif. Pada tahun 2016 terdapat enam kinerja saham yang positif, yaitu: AALI, BISI, DSFI, LSIP, SGRO, dan SIMP, sedangkan tiga saham lainnya memiliki kinerja negatif.

Berdasarkan perhitungan dengan menggunakan metode sharpe, treynor, dan jensen, hasil analisis tersebut menunjukkan kinerja saham yang sama.

Tabel 4.8

Kinerja Saham Syariah Metode Sharpe

\begin{tabular}{|c|c|c|c|c|}
\hline No & $\begin{array}{c}\text { Saham } \\
\text { Syariah }\end{array}$ & $\begin{array}{c}\text { Rata-Rata 5 } \\
\text { Tahun } \\
\text { Sharpe }\end{array}$ & $\begin{array}{c}\text { Rata-Rata 5 } \\
\text { Tahun } \\
\text { IHSG }\end{array}$ & Kinerja \\
\hline 1 & AALI & -0.03071 & $1.3154 \mathrm{E}-05$ & UNDER PERFORM \\
\hline 2 & BISI & 0.083913 & $1.3154 \mathrm{E}-05$ & OUT PERFORM \\
\hline 3 & BTEK & 0.00707 & $1.3154 \mathrm{E}-05$ & OUT PERFORM \\
\hline 4 & DSFI & 0.098858 & $1.3154 \mathrm{E}-05$ & OUT PERFORM \\
\hline 5 & GZCO & -0.27818 & $1.3154 \mathrm{E}-05$ & UNDER PERFORM \\
\hline 6 & IIKP & 0.131399 & $1.3154 \mathrm{E}-05$ & OUT PERFORM \\
\hline 7 & LSIP & 0.003785 & $1.3154 \mathrm{E}-05$ & OUT PERFORM \\
\hline 8 & SGRO & -0.08198 & $1.3154 \mathrm{E}-05$ & UNDER PERFORM \\
\hline 9 & SIMP & -0.20509 & $1.3154 \mathrm{E}-05$ & UNDER PERFORM \\
\hline
\end{tabular}

Tabel 4.8 menunjukkan bahwa kinerja saham syariah dengan menggunakan metode Sharpe selama lima tahun, yaitu tahun 2012 sampai tahun 2016 yang dibandingkan dengan banchmark (IHSG), terdapat empat saham syariah yang Under Perform, yaitu PT. Astra Agro Lestari Tbk (AALI), PT Gozco Plantations Tbk (GZCO), PT Sampoerna Agro Tbk (SGRO), dan PT Salim Ivomas Pratama Tbk (SIMP), sedangkan lima saham syariah lainnya Out Perform, yaitu PT BISI International Tbk (BISI), PT Bumi Teknokultura Unggul Tbk (BTEK), PT Dharma Samudera Fishing Industries Tbk (DSFI), PT Inti Agri Resources Tbk (IIKP), dan PT PP London Sumatra Indonesia Tbk (LSIP).

Tabel 4.9

Kinerja Saham Syariah Metode Treynor

\begin{tabular}{|c|c|c|c|l|}
\hline No & $\begin{array}{c}\text { Saham } \\
\text { Syariah }\end{array}$ & $\begin{array}{c}\text { Rata- } \\
\text { Rata 5 } \\
\text { Tahun } \\
\text { Treynor }\end{array}$ & $\begin{array}{c}\text { Rata- } \\
\text { Rata 5 } \\
\text { Tahun } \\
\text { IHSG }\end{array}$ & Kinerja \\
\hline 1 & AALI & -13.9517 & 0.001074 & UNDER PERFORM \\
\hline 2 & BISI & 30.21421 & 0.001074 & OUT PERFORM \\
\hline 3 & BTEK & 17.14971 & 0.001074 & OUT PERFORM \\
\hline 4 & DSFI & 19.39283 & 0.001074 & OUT PERFORM \\
\hline 5 & GZCO & -87.8684 & 0.001074 & UNDER PERFORM \\
\hline 6 & IIKP & 33.05748 & 0.001074 & OUT PERFORM \\
\hline 7 & LSIP & -2.83928 & 0.001074 & UNDER PERFORM \\
\hline 8 & SGRO & -23.877 & 0.001074 & UNDER PERFORM \\
\hline 9 & SIMP & -84.3299 & 0.001074 & UNDER PERFORM \\
\hline
\end{tabular}


Tabel 4.9 menunjukkan bahwa kinerja saham syariah dengan menggunakan metode Treynor selama lima tahun, yaitu tahun 2012 sampai tahun 2016 yang dibandingkan dengan Benchmark (IHSG), terdapat lima saham syariah yang Under Perform, yaitu PT. Astra Agro Lestari Tbk (AALI), PT Gozco Plantations Tbk (GZCO), PT PP London Sumatra Indonesia Tbk (LSIP), PT Sampoerna Agro Tbk (SGRO), dan PT Salim Ivomas Pratama Tbk (SIMP), sedangkan empat saham syariah lainnya Out Perform, yaitu PT BISI International Tbk (BISI), PT Bumi Teknokultura Unggul Tbk (BTEK), PT Dharma Samudera Fishing Industries Tbk (DSFI), dan PT Inti Agri Resources Tbk (IIKP).

Kinerja saham syariah dengan menggunakan metode Jensen tidak dapat diambil keputusan apakah saham syariah mempunyai kinerja Under Perform ataupun Out Perform, karena nilai Benchmark (IHSG) sebagi pembanding mempunyai nilai O. Oleh karena itu, saham syariah yang mempunyai kinerja Out Perform layak dipilih dan dimiliki investor untuk berinvestasi, untuk saham yang mempunyai kinerja Under Perform kurang layak dipilih dan dimiliki oleh investor untuk berinvestasi.

Tabel 4.10

Ranking Saham Syariah Metode Sharpe, Treynor dan Jensen

Periode Tahun 2012-2016

\begin{tabular}{|c|l|c|c|c|}
\hline No & $\begin{array}{c}\text { Saham } \\
\text { Syariah }\end{array}$ & $\begin{array}{c}\text { Ranking } \\
\text { Sharpe }\end{array}$ & $\begin{array}{c}\text { Ranking } \\
\text { Treynor }\end{array}$ & $\begin{array}{c}\text { Ranking } \\
\text { Jensen }\end{array}$ \\
\hline 1 & IIKP & 1 & 1 & 1 \\
\hline 2 & DSFI & 2 & 3 & 2 \\
\hline 3 & BISI & 3 & 2 & 3 \\
\hline 4 & BTEK & 4 & 4 & 4 \\
\hline 5 & LSIP & 5 & 5 & 5 \\
\hline 6 & AALI & 6 & 6 & 6 \\
\hline 7 & SGRO & 7 & 7 & 7 \\
\hline 8 & SIMP & 8 & 8 & 8 \\
\hline
\end{tabular}

\begin{tabular}{|l|l|l|l|l|}
\hline 9 & GZCO & 9 & 9 & 9 \\
\hline
\end{tabular}

Tabel 4.10 menunjukkan bahwa saham syariah PT Inti Agri resources Tbk (IIKP) konsisten rangking pertama, baik metode sharpe, treynor, ataupun metode jensen. Saham syariah PT Dharma Samudera Fishing Industries Tbk (DSFI), menempati rangking dua pada metode sharpe dan jensen, sedangkan metode treynor menempati rangking tiga. Saham syariah PT BISI International Tbk (BISI), menempati rangking tiga pada metode sharpe dan jensen, sedangkan metode treynor menempati rangking dua. Saham syariah PT Bumi Teknokultura Unggul Tbk (BTEK), PT PP London Sumatra Indonesia Tbk (LSIP), PT Astra Agro Lestari Tbk (AALI), PT Sampoerna Agro Tbk (SGRO), PT Salim Ivomas Pratama Tbk (SIMP), dan PT Gozco Plantations Tbk (GZCO), konsisten pada rangking empat, lima, enam, tujuh, delapan, dan sembilan, baik menggunakan metode sharpe, treynor, ataupun metode jensen.

\section{Simpulan dan Implikasi}

Berdasarkan yang sudah dipaparkan diatas, maka simpulan dan implikasinya adalah:

1. Kinerja saham syariah dengan menggunakan metode Sharpe terdapat empat saham syariah yang Under Perform, yaitu PT. Astra Agro Lestari Tbk (AALI), PT Gozco Plantations Tbk (GZCO), PT Sampoerna Agro Tbk (SGRO), dan PT Salim Ivomas Pratama Tbk (SIMP), serta ada lima saham syariah yang Out Perform, yaitu PT BISI International Tbk (BISI), PT Bumi Teknokultura Unggul Tbk (BTEK), PT Dharma Samudera Fishing Industries Tbk (DSFI), PT Inti Agri Resources Tbk (IIKP), dan PT PP 
London Sumatra Indonesia Tbk (LSIP).

2. Kinerja saham syariah dengan menggunakan metode Treynor terdapat lima saham syariah yang Under Perform, yaitu PT. Astra Agro Lestari Tbk (AALI), PT Gozco Plantations Tbk (GZCO), PT PP London Sumatra Indonesia Tbk (LSIP), PT Sampoerna Agro Tbk (SGRO), dan PT Salim Ivomas Pratama Tbk (SIMP), serta empat saham syariah yang Out Perform, yaitu PT BISI International Tbk (BISI), PT Bumi Teknokultura Unggul Tbk (BTEK), PT Dharma Samudera Fishing Industries Tbk (DSFI), dan PT Inti Agri Resources Tbk (IIKP).

3. Kinerja saham syariah dengan menggunakan metode Jensen tidak dapat diambil keputusan apakah saham syariah mempunyai kinerja Under Perform ataupun Out Perform, karena nilai Benchmark (IHSG) sebagi pembanding mempunyai nilai $\mathrm{O}$.

4. Jika dilihat dari segi rangking, saham syariah PT Inti Agri resources Tbk (IIKP) konsisten rangking pertama dan rangking sembilan adalah PT Gozco Plantations Tbk (GZCO), baik menggunakan metode sharpe, treynor, ataupun metode jensen.

5. Analisis kinerja saham syariah ini, dapat membantu para Investor untuk mengetahui dan memilih saham syariah mana yang out perform dan rangkingnya baik, sehingga investor dapat berinveastasi pada saham syariah tersebut.

\section{DAFTAR PUSTAKA}

Anita. 2016. Analisis Perbandingan Kinerja Saham Syariah Sebelum dan Sesudah Pengumuman Kenaikan BBM. Jurnal Kajian Ekonomi Islam, Volume.1, No.1. Diakses pada 31 Januari 2017.

Hartono, Jogiyanto. 2014. Teori Portofolio dan Analisis Investasi. Edisi Kesepuluh. Yogyakarta: BPFE.

Bapepam-LK. 2012. Kriteria dan Penerbitan Daftar Efek Syariah. Jakarta: Bapepam-LK. . Peraturan Bapepam-LK

No.II.K.1 tentang Kriteria dan Penerbitan Daftar Efek syariah. Jakarta: Bapepam-LK.

Dewan Syari'ah Nasional. 2007. Obligasi Syariah Mudharabah Konversi. Jakarta: Dewan Syari'ah Nasional-Majelis Ulama Indonesia.

Dewan Syari'ah Nasional. 2011. Fatwa Dewan Syari'ah Nasional No:80/DSN-MUI/III/2011 tentang Penerapan Prinsip Syariah dalam Mekanisme Perdagangan Efek Bersifat Ekuitas di Pasar Reguler Bursa Efek. Jakarta: Dewan Syari'ah Nasional-Majelis Ulama Indonesia.

Hasanah, Uswatun. 2011. Perbandingan Kinerja Saham Syariah 20072009. Skripsi. Jakarta: UIN Syarif Hidayatullah. Diakses pada tanggal 31 Januari 2017

Moleong, L.J. 2014. Metode Penelitain Kualitatif Edisi Revisi. Bandung: Remaja Rosdakarya.

Otoritas Jasa Keuangan Republik Indonesia. 2015. Peraturan Otoritas Jasa Keuangan Nomor 15/POJK.04/2015 tentang Penerapan Prinsip Syariah di Pasar Modal. Jakarta: Otoritas Jasa Keuangan Republik Indonesia. 
Otoritas Jasa Keuangan Republik Indonesia. 2015. Peraturan Otoritas Jasa Keuangan Nomor 16/POJK.04/2015 tentang Ahli Syariah Pasar Modal. Jakarta: Otoritas Jasa Keuangan Republik Indonesia.

Otoritas Jasa Keuangan Republik Indonesia. 2015. Peraturan Otoritas Jasa Keuangan Nomor 17/POJK.04/2015 tentang Penerbitan dan Penyertaan Efek Syariah Berupa Saham oleh emiten Syariah atau Perusahaan Publik syariah. Jakarta: Otoritas Jasa Keuangan Republik Indonesia.

Otoritas Jasa Keuangan Republik Indonesia. 2015. Peraturan Otoritas Jasa Keuangan Nomor 18/POJK.04/2015 tentang Penerbitan dan Persyaratan sukuk. Jakarta: Otoritas Jasa Keuangan Republik Indonesia.

Otoritas Jasa Keuangan Republik Indonesia. 2015. Peraturan Otoritas Jasa Keuangan Nomor 20/POJK.04/2015 tentang Penerbitan dan Persyaratan Efek Beragun Aset Syariah. Jakarta: Otoritas Jasa Keuangan Republik Indonesia.

Otoritas Jasa Keuangan Republik Indonesia. 2015. Peraturan Otoritas Jasa Keuangan Nomor 53/POJK.04/2015 tentang Akad yang digunakan dalam Penerbitan Efek Syariah di Pasar Modal. Jakarta: Otoritas Jasa Keuangan Republik Indonesia.

Otoritas Jasa Keuangan Republik Indonesia. 2016. Statistik Pasar Modal Syariah. Jakarta: Direktorat Pasar Modal Syariah Republik Indonesia.
Otoritas Jasa Keuangan Republik Indonesia. 2016. Keputusan Dewan Komisioner Otoritas Jasa Keuangan No.22 Tahun 2016 tentang Daftar Efek Syariah. Jakarta: Otoritas Jasa Keuangan Republik Indonesia.

Otoritas Jasa Keuangan Republik Indonesia. 2016. Roadmap Pasar Modal Syariah 2015-2019. Jakarta: Otoritas Jasa Keuangan Republik Indonesia.

Presiden Republik Indonesia. 1995. Undang-undang Nomor 8 Tahun 1995 tentang Pasar Modal. Jakarta: Menteri Negara Sekretaris Negara RI.

Sugiyono. 2014. Metode Penelitian Kuantitatif, Kualitatif, dan Kombinasi (Mixed Method). Bandung: Alfabeta. . 2014. Metode Penelitian Kuantitatif, Kualitatif, dan R\&D. Bandung: Alfabeta.

Teurah, Citrayani. 2013. Perbandingan Kinerja Saham LQ 45 Tahun 2012 Menggunakan Metode Jensen, Sharpe Dan Treynor. Jurnal Emba. Vol.1 No.4 Desember 2013, Hal. 1444-1457. Diakses pada 31 Januari 2017.

Waridah, Wirda, dan Mediawati, Ellis. 2016. Analisis Kinerja Reksadana Syariah. Jurnal Riset Akuntansi \& Keuangan FEB UPI, Vol 4. No.12. 142-153. 